\title{
Formulation and Evaluation of Some Novel Food Products Containing Plant (Vegan) Milks
}

\author{
Ayah, M. El-Hossainy ${ }^{1}$, Ahmed, S.M. ${ }^{1}$, Kheder, I.E. ${ }^{2}$, Sohair, F. Nour ${ }^{1}$ \& El-Sawy ${ }^{1}$, N.M. \\ 1- Home Economic Dept., Fac. of Agric., Alexandria University, 21545, El-Shatby, Alexandria, Egypt. \\ 2- Dairy Science and Technology Dept., Fac. of Agric., Alexandria University, 21545, El-Shatby, Alexan- \\ dria, Egypt.
}

Received: 3 December, 2020

Revised: 5 October, 2021

Accepted: 31 October, 2021

\begin{abstract}
Some plant (vegan) milks were prepared, namely brown rice milk, coconut milk and almond milk. Moreover, strawberry fermented milk, and non-fermented milk, chocolate pudding and spreadable cheddar cheese were made. Chemical composition revealed that almond milk possessed significantly $(\mathrm{P} \leq 0.05)$ the highest protein content $(6.1 \%)$ on contrary to coconut milk being the significantly $(\mathrm{P} \leq 0.05)$ lowest content $(2.3 \%)$. Meanwhile, almond and milk exhibited significantly $(\mathrm{P} \leq 0.05)$ the highest contents of each of the following mineral elements: potassium, calcium, zinc and magnesium. Sensory evaluation indicated that strawberry milk made from almond milk and coconut milk were superior in acceptability by panelists in contrast, strawberry milk made from cow's milk was ranked significantly $(\mathrm{P} \leq 0.05)$ as the least acceptable. The most favorable sensorial properties were figured out for strawberry milk $+50 \%$ coconut milk stored for one day. Generally, the best sensorial properties for cheddar cheese were traced for samples made from $70 \%$ rice milk $+30 \%$ almond milk.
\end{abstract}

Keywords: Cow's milk, rice milk, coconut milk, almond milk, fermented milk, spreadable Cheddar cheese, chocolate pudding, Sensory evaluation.

\section{INTRODUCTION}

In Western countries, plant-based milk food products are well known. Such products have health benefits for persons suffering from lactose intolerance or those who are allergic to milk proteins. Meanwhile, plant sources are considered as functional foods owing to presence of health promoting compounds such as dietary fibers, minerals, vitamins and antioxidants (Lee, 2014).

Consumption of dairy products has been reported to decline since 1970. Such a trend is related to consumers desire for healthier and more environmentally friendly (Schott \& Bernard, 2015, Mäkinen et al., 2016). Theoretically, plant milks are defined as water extracts of legumes, oil seeds, cereals or pseudo cereals that resemble cow milk in appearance (Mäkinen et al., 2016). Consequently, many plant sources (soy beans, almonds, coconut and rice can be utilized for formulating non-dairy products. it is worth to mention that the most current dietary guidelines 2015-2020 recognized soy milk as a part of the dairy group due to its similarity in nutrition to cow milk (USDA, 2013).
It is worth to mention that a number of consumers are opting for plant-based milk alternatives for dietary restrictions such as vegetarian vegan diet or those with medical conditions such as lactose intolerance, which affects $75 \%$ of the worldwide population, are replacing traditional cow milk for a plant-based substitute (Mäkinen et. al., 2016).

The present study was carried out to prepare and evaluate different types of plant milks (Vegan milk) from coconut, almonds and rice grains. Moreover, some food products were prepared using the aforementioned plant milks. These food products were evaluated from physicochemical and sensorial points of view.

\section{MATERIALS AND METHODS}

\section{Materials:}

Raw materials were purchased from the local market, Alexandria, Egypt. Flavouring agents were obtained from AWA Company Borg Al-Arab, Alexandria, Egypt. Probiotics were obtained from Protexin Health Care Company, United Kingdom. 


\section{Preparation of plant (Vegan) milks:}

Brown rice milk, coconut milk and almond milk were formulated as shown in Table (1) Ingredients of plant milk formulation :

Table 1: Formulation of vegan milks

\begin{tabular}{lccc}
\hline \multirow{2}{*}{ Ingredients } & $\begin{array}{c}\text { Brown rice } \\
\text { milk }\end{array}$ & $\begin{array}{c}\text { Coconut } \\
\text { milk }\end{array}$ & $\begin{array}{c}\text { Almond } \\
\text { milk }\end{array}$ \\
\cline { 2 - 4 } & Wight & Wight & Wight \\
\hline Raw material $(\mathrm{g})$ & 200 & 200 & 200 \\
Filtered water $(\mathrm{ml})$ & 1000 & 800 & 800 \\
Vanillin (g) & 1 & 1 & 1 \\
Maple syrup (g) & 3 & 3 & 3 \\
Salt (g) & 1 & 1 & 1 \\
\hline
\end{tabular}

\section{Preparation of food products containing} plant milks:

\section{Strawberry flavoured plant milks:}

Four types of milk (skimmed cow's milk, rice milk, coconut milk and almond milk) were formulated as shown in Table (2)

Strawberry flavour was added to each of the plant milk used in the present study. Thereafter, the milk was heated at $90^{\circ} \mathrm{C}$ for $10 \mathrm{~min}$, followed by storage for 14 days at $4^{\circ} \mathrm{C}$

\section{Chocolate pudding}

The four types of milk (skimmed milk, rice milk, coconut milk and almond milk) were prepared then sugar and chocolate pudding powder were added to each of milk preparation. Each sample was heated at $90^{\circ} \mathrm{C}$ for $10 \mathrm{~min}$. The mixture was stored at $\left(4^{\circ} \mathrm{C}\right)$ for different stronge periods.

\section{Strawberry fermented milk}

It was consisted of four recipes
A. $100 \%$ brown rice milk
B. $90 \%$ brown rice milk $+10 \%$ coconut milk

Table 2 : Ingredient
plant milks

\begin{tabular}{lllll}
\hline \multicolumn{1}{c}{ Ingredients } & $\begin{array}{c}\text { Skimmed } \\
\text { milk }\end{array}$ & $\begin{array}{c}\text { Rice } \\
\text { milk }\end{array}$ & $\begin{array}{c}\text { Coconut } \\
\text { milk }\end{array}$ & $\begin{array}{c}\text { Almond } \\
\text { milk }\end{array}$ \\
\hline Milk (ml) & 1000 & 1000 & 1000 & 1000 \\
Strawberry Syrup (g) & 30 & 30 & 30 & 30 \\
Frozen strawberries $(\mathrm{g})$ & 20 & 20 & 20 & 20 \\
Vanillin (g) & 2 & 2 & 2 & 2 \\
maple syrup (g) & 3 & 3 & 3 & 3 \\
\hline
\end{tabular}

C. $70 \%$ brown rice milk $+30 \%$ coconut milk

D. $50 \%$ brown rice milk $+50 \%$ coconut milk

Vanillin, sugar and carrageenan were added to each sample, all samples were heated at $90^{\circ} \mathrm{C}$ for $20 \mathrm{~min}$. After cooling, the probiotic and strawberry syrup were added to each sample. Finally samples were poured into sterilized bottles and were incubated at $42^{\circ} \mathrm{C}$ for $7 \mathrm{hr}$, then stored at $4^{\circ} \mathrm{C}$ for different storage periods.

\section{Spreadable cheddar cheese}

It was consisted of four recipes
A. $100 \%$ brown rice milk
B. $90 \%$ brown rice milk $+10 \%$ almond milk
C. $70 \%$ brown rice milk $+30 \%$ almond milk
D. $50 \%$ brown rice milk $+50 \%$ almond milk

Starch, salt, coconut oil, carrageenan, cheese flavour and natural colour were added to each sample. Each sample was heated at $90^{\circ} \mathrm{C}$ for $10 \mathrm{~min}$. It was stored for 14 days at $4^{\circ} \mathrm{C}$.

\section{Analytical methods:}

\section{Physical methods:}

\section{Viscosity measurement}

Viscosity of plant milks and formulated food products was measured by digital rotary Viscometers MYR (VR 300- Model L, Viscotech Hispania S.L, El Vendrell, Spain). According to Nilsson et al. (2006).

\section{Colour measurement:}

Colour of plant milks and formulated food products was measured by Hunter high performance spectrophotometer (UltraScan ${ }^{\circledR}$, Hunter Associates Laboratory Inc., Va, USA).The tristimuls values for colour namely: $L^{*}, a^{*}$ and $b^{*}$ were measured where: $\mathrm{L}^{*}$ : represents darkness from black (0) to white (100), a*represents colour ranging from red $(+)$ to green $(-)$ and $b^{*}$ represents yellow $(+)$ to blue $(-)$.

\section{Texture profile:}

The texture profile analysis was carried out on fresh samples of Cheddar spread cheese and chocolate pudding. Wasused Texture analyzer (model TA1000, Lab Pro (FTC TMS-Pro, USA) was used as outlined by the International Dairy Federation (1991). The following parameters were evaluated : 

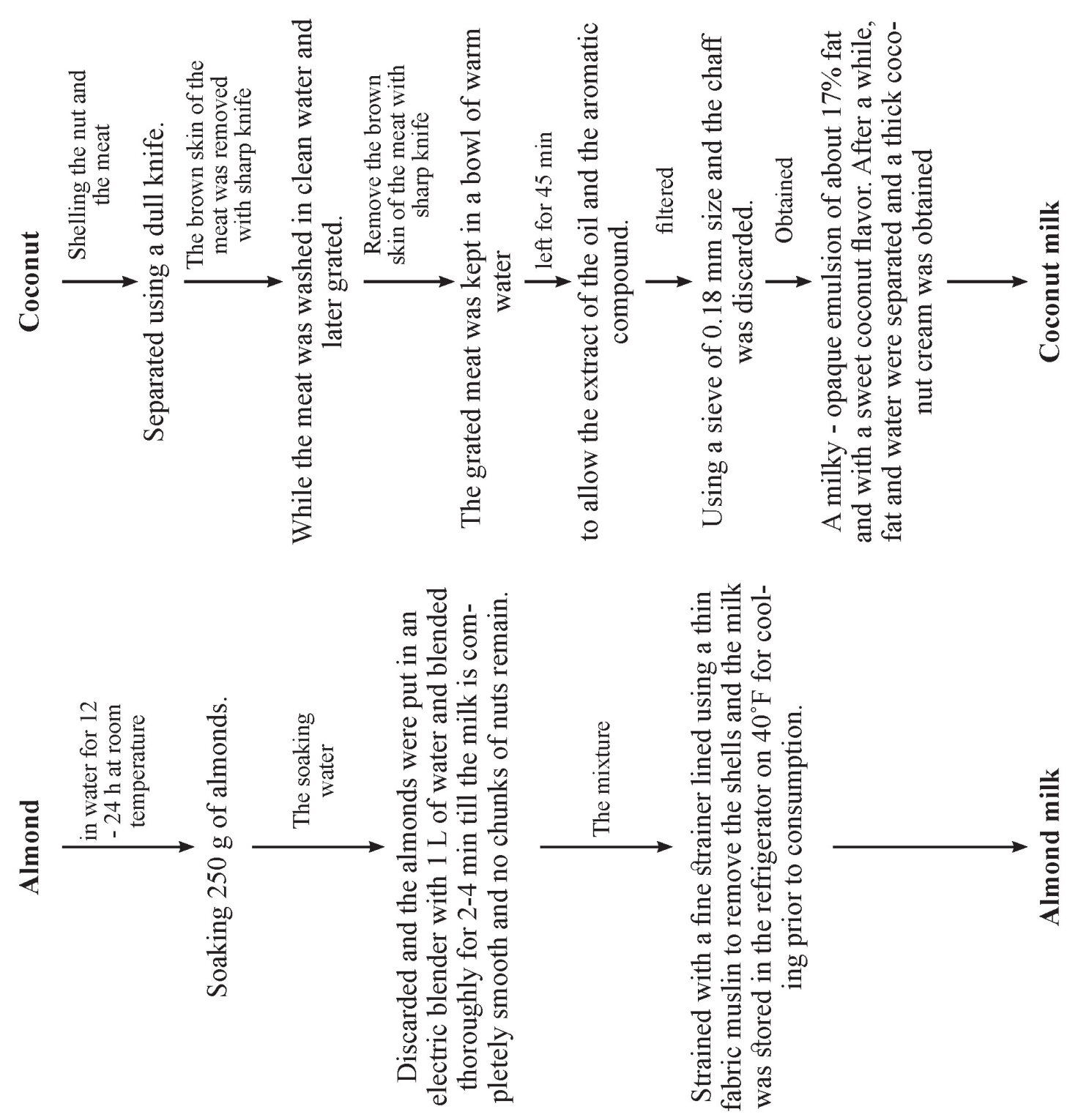

资

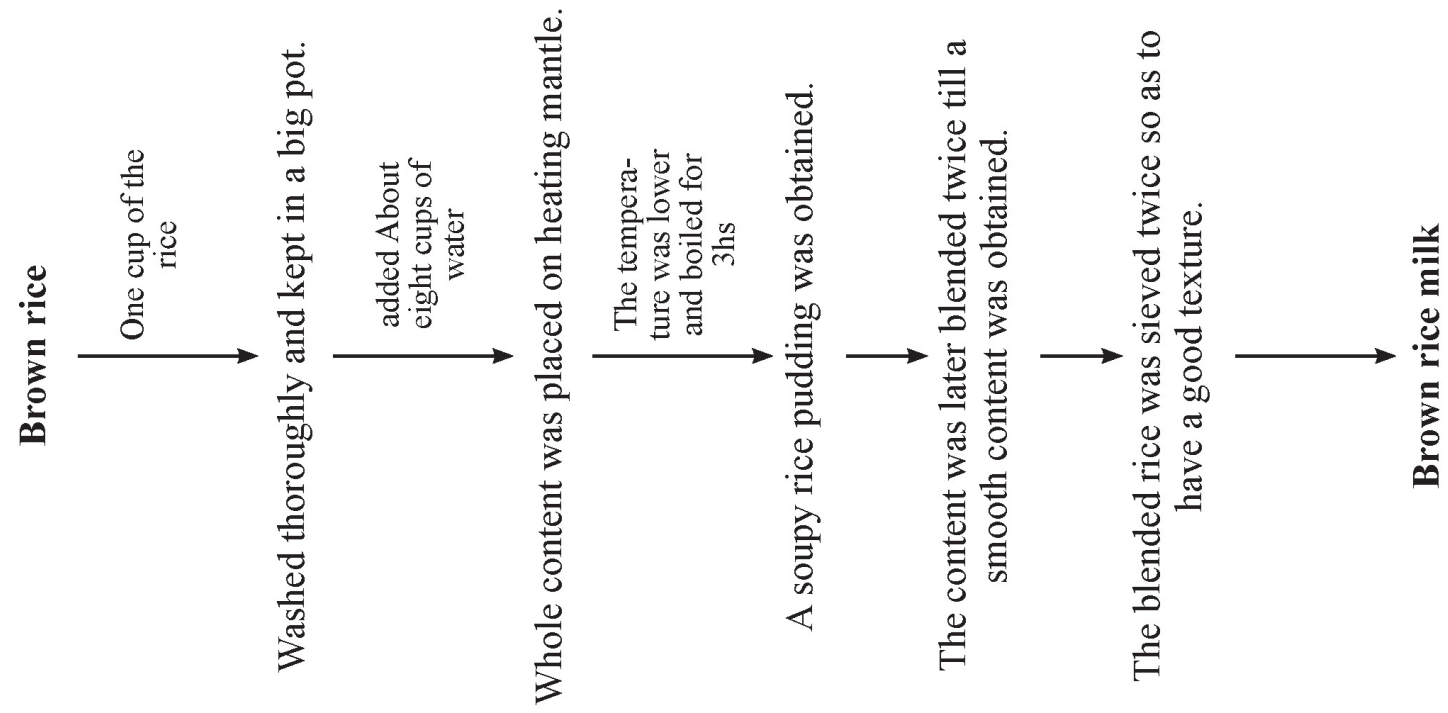


- Hardness (kilogram, g): the force required to produce a given deformation,

- Springiness ( $\mathrm{mm})$ : the rate at which a deformed material goes back to it's under formed condition after the deforming force is removed,

- Gumminess (g): the quantity to simulate the energy required to disintegrate a semisolid food product to a state ready to swallowing, (Gumminess $=$ hardness $\times$ cohesiveness) and

- Chewiness (mi): the quantity to simulate the energy required to masticate a solid food product to a state ready for swallowing, (chewiness $=$ gumminess $\mathrm{x}$ springiness)

\section{Chemical methods:}

Gross chemical composition of milk and vegan milk was determined according to the AOAC (2006). Dietary fiber was determined using an ANKOM 220 fiber analyzer according to AOAC (2006).

The $\mathrm{pH}$ of milk and vegan milk was measured by digital $\mathrm{pH}$ meter (Basic20 PH-Meter; Crison Instruments, Barcelona, EU.

Starch content of milk and vegan milk was determined spectrophotometrically (thermoscientific, MESLOcompany, Egypt according to AOAC (2006) . Mineral elements were determined according to AOAC method (2006) by Atomic Absorption Spectromphotometer (Thermo Scientific,MESLO Company, Cairo, Egypt)

\section{Sensory evaluation:}

Organoleptic properties were assessed for fresh samples and stored samples for 7 and 14 days as described by Tamime et al. (2006). The panel group consisted of ten panelists from staff members and postgraduate students, Department of Dairy Science and Technology, Faculty of Agriculture, University of Alexandria .

\section{Microbiological assay:}

The microbiological analysis of different vegan products were carried out according to IDF Standard method 122 C (1996). The total viable bacterial counts were enumerated on plate count agar medium at $32^{\circ} \mathrm{C}$ for $48 \mathrm{~h}$ as described by Harrigan and McCance (1976).

Yoghurt samples were tenfold serially diluted in $0.15 \%$ sterile peptone water. Using drop plate method, $20 \mu 1$ of each dilution was plated in triplicate on selective media as described by Kleessen et al. (1997). S. thermophilus was enumerated on S. thermophilus agar medium (ST agar) and incubated aerobically at $37^{\circ} \mathrm{C}$ for $24 \mathrm{hr}$. Lb. bulgaricus was counted on MRS adjusted to $\mathrm{pH} 5.2$ and inocubated anaerobically at $45^{\circ} \mathrm{C}$ for $72 \mathrm{~h}$. B. lactis was enumerated on MRS agar and incubated anaerobically at $37^{\circ} \mathrm{C}$ for $72 \mathrm{hr}$.

Coliform bacteria were determined using violet red bile agar medium after incubation at $37^{\circ} \mathrm{C}$ for $24 \mathrm{hr}$ (Harrigan et al., 1976). Counts of aerobic spore forming bacteria were determined on nutrient agar medium at $37^{\circ} \mathrm{C}$ (Wehr et al., 2004). Molds and yeasts were enumerated on potato dextrose agar medium and plates were incubated at $25 \pm 2^{\circ} \mathrm{C}$ for 5 days (International Dairy Federation, 1991).

\section{Statistical analysis:}

The data were statistically analyzed by oneway ANOVA according to SAS statistical software. The significant differences among means were assessed by Duncan's multiple range test (Duncan, 1955).

\section{RESULT AND DISCUSSION}

\section{Physicochemical properties of Vegan milks:}

The data presented in Table (3) show the physicochemical properties of brown rice milk (BRM) , coconut milk (CM) and almond milk (AM). Total solids varied from $21.8 \%$ to $22.98 \%$. It was obvious that $\mathrm{CM}$ possessed the significantly $(\mathrm{P} \leq 0.05)$ highest total solids as compared to BMR and AM. The AM had the significantly $(\mathrm{P} \leq 0.05)$ highest crude protein content $(6.10 \%)$ on contrary to $\mathrm{CM}$ which exhibited the significantly least $(\mathrm{P} \leq 0.05)$ crude protein content being 2-3\%, while BRM had value of (4.66\%).(Table3).

Crude fat revealed a wide range of variation $(0.77-12.80 \%)$ in the three vegan milks under study. The CM had the significantly highest $(\mathrm{P} \leq 0.05)$ crude fat content $(12.80 \%)$ while BRM exhibited the significantly $(\mathrm{P} \leq 0.05)$ lowest content $(0.77 \%)$. Table (3) shows that BRM had the significantly $(\mathrm{P} \leq 0.05)$ total carbohydrate content $(3.2 \%)$ while $\mathrm{CM}$ and $\mathrm{AM}$ were quite comparable in this regard since both had 5.6\%. Dietary fiber content ranged from $2.2 \%(\mathrm{CM})$ to $2.9 \%(\mathrm{AM})$, while BRM had $2.70 \%$ dietary fiber (Table 3 ). 
Table 3: Physicochemical properties of some vegan milks (BRM, CM and AM)

\begin{tabular}{llll}
\hline \multicolumn{1}{c}{ Parameters (\%) } & \multicolumn{1}{c}{ BRM } & \multicolumn{1}{c}{ CM } & AM \\
\hline Total Solids & $21.80^{\mathrm{c}}$ & $22.98^{\mathrm{a}}$ & $22.70^{\mathrm{b}}$ \\
Crude Protein & $4.66^{\mathrm{b}}$ & $2.30^{\mathrm{c}}$ & $6.10^{\mathrm{a}}$ \\
Total Fat & $0.77^{\mathrm{c}}$ & $12.80^{\mathrm{a}}$ & $7.20^{\mathrm{b}}$ \\
Total Carbohydrate\% & $13.20^{\mathrm{a}}$ & $5.50^{\mathrm{b}}$ & $5.60^{\mathrm{b}}$ \\
Dietary Fiber & $2.70^{\mathrm{b}}$ & $2.20^{\mathrm{c}}$ & $2.90^{\mathrm{a}}$ \\
Starch & 0.47 & $0.01^{\mathrm{c}}$ & 0.03 \\
Ash & 0.11 & 0.18 & 0.87 \\
Acidity & 0.11 & 0.17 & 0.14 \\
pH & 6.74 & 6.71 & 6.30 \\
\hline
\end{tabular}

$\mathrm{BRM}=$ Brown Rice milk, $\mathrm{CM}=$ Coconut Milk, $\mathrm{AM}=$ Almond milk

Table (3) shows that BRM, CM, and AM varied in terms of their contents of starch $(0.01$ $0.47 \%)$, ash (0.11-0.87) and acidity (0.11-0.17\%). Moreover, the aforementioned milks varied in their $\mathrm{pH}$ values being in a range from 6.30 (AM) to 6.74 (BRM).

The data presented here regarding the investigated physicochemical properties of the three vegan milks are in agreement with numerous published data (Kolapo et al., 2012).

\section{Mineral composition of vegan milks:}

Table (4) shows the mineral composition of the three vegan milks under study (BRM, CM and $\mathrm{AM})$. It was clear that $\mathrm{CM}$ had the significantly highest $(\mathrm{P} \leq 0.05)$ contents of six out of ten elements that were determined. Notwithstanding, AM exhibited significantly $(\mathrm{P} \leq 0.05)$ the highest values for calcium $(60.6 \mathrm{mg} / 100 \mathrm{~g})$, phosphorus $(134 \mathrm{mg}$ $1100 \mathrm{~g})$ and potassium $(192 \mathrm{mg} / 100 \mathrm{~g})$. The point of interest is that these figures are extremely higher than those belonging to both BRM and CM. The data presented here are in accordance with data published elsewhere (Kartz et al., 2014).

\section{Colour of raw materials and vegan milks}

Colour measured by Hunter instrument (Table 5) revealed that brightness $\left(\mathrm{L}^{*}\right)$ for rice, coconut and almond ranged between 61.24 (rice milk) and 83.40 (coconut milk) almond while $\mathrm{L}^{*}$ value of 80.97. Table (5) shows that the three straw vegan milks had L* value ranged between 45.33 and 54.19 as compared to strawberry cow's milk being 54.48. On the other hand, blends of BRM and CM exhibited $\mathrm{L}^{*}$ value ranged from 68.48 (90\% BRM $+10 \% \mathrm{CM})$ to $70.19(50 \% \mathrm{BRM}+50 \% \mathrm{CM})$.
Table 4: Mineral composition $(\mathrm{mg} / 100 \mathrm{ml})$ of some vegan milks (BRM, CM and AM)

\begin{tabular}{llll}
\hline \multicolumn{1}{c}{ Minerals } & BRM & CM & AM \\
\hline Phosphorus & $92.2^{\mathrm{c}}$ & $100^{\mathrm{b}}$ & $134^{\mathrm{a}}$ \\
Magnesium & $11.6^{\mathrm{c}}$ & $37^{\mathrm{b}}$ & $77^{\mathrm{a}}$ \\
Potassium & $11.3^{\mathrm{c}}$ & $263^{\mathrm{a}}$ & $192^{\mathrm{b}}$ \\
Calcium & $2.6^{\mathrm{c}}$ & $16^{\mathrm{b}}$ & $60.6^{\mathrm{a}}$ \\
Sodium & $1.3^{\mathrm{c}}$ & $15^{\mathrm{a}}$ & $7.8^{\mathrm{b}}$ \\
Iron & $0.1^{\mathrm{c}}$ & $1.6^{\mathrm{a}}$ & $1^{\mathrm{b}}$ \\
Zinc & $0.2^{\mathrm{c}}$ & $0.7^{\mathrm{b}}$ & $0.9^{\mathrm{a}}$ \\
Manganese & $0.3^{\mathrm{c}}$ & $0.9^{\mathrm{a}}$ & $0.6^{\mathrm{b}}$ \\
Copper & $0.0^{\mathrm{b}}$ & $0.3^{\mathrm{a}}$ & $0.3^{\mathrm{a}}$ \\
\hline
\end{tabular}

$\mathrm{BRM}=$ Brown Rice milk, $\mathrm{CM}=$ Coconut Milk, $\mathrm{AM}=$ Almond milk

Super scrip letters following numbers in the same row demote significant differences $(\mathrm{P} \leq 0.05)$

Table 5: Colour measurements of raw materials and vegan milks as compared to cow's milk

\begin{tabular}{lccc}
\hline \multirow{2}{*}{ Samples } & \multicolumn{3}{c}{ Colour } \\
\cline { 2 - 4 } Cow's milk & $\mathbf{L} * \mathbf{1}$ & $\mathbf{a * 2}$ & $\mathbf{b * 3}$ \\
\hline Rice milk & 62.47 & 1.72 & 6.72 \\
Coconut milk & 83.40 & -0.97 & 1.14 \\
Almond milk & 80.97 & 1.66 & 7.67 \\
strawberry Cow's milk & 54.48 & 19.04 & 0.39 \\
strawberry Rice milk & 45.33 & 23.88 & -1.72 \\
strawberry Coconut milk & 54.19 & 20.43 & 1.79 \\
strawberry Almond milk & 59.41 & 20.21 & -1.12 \\
100\% Rice milk & 63.27 & 10.37 & 3.07 \\
90\% Rice milk+ 10\% & 68.48 & 10.38 & 2.47 \\
Coconut milk & & & \\
70\% Rice milk+ 30\% & 68.77 & 10.71 & 1.71 \\
Coconut milk & & & \\
50\% Rice milk+ 50\% & 70.19 & 10.94 & 1.46 \\
Coconut milk & & & \\
\hline
\end{tabular}

*1 L*: lightness, *2: a*: redness and *3 b*yellowness

Redness value ( $a^{*}$ ) ranged from -2.86 for rice to 1.72 for cow's milk. Strawberry cow's milk had the least $\mathrm{a}^{*}$ value being 19.04 on contrary to the strawberry rice milk values (23.88).It is worth to note that $\mathrm{a}^{*}$ values for BRM and its blends with $\mathrm{CM}$ were quite comparable (Table 5). 
The yellowness value $\left(b^{*}\right)$ ranged between 1.14 (cocount milk) and 7.67 (almond milk) for the raw materials used in the present study (Table 5). Not with standing, $b^{*}$ values ranged from -1.72 (strawberry BRM) to 1.79 (straw CM). Table (5) shows that $b^{*}$ ranged from 1.46 (blend of $50 \%$ $\mathrm{BRM}+50 \% \mathrm{CM})$ to $3.07(100 \% \mathrm{BRM})$.

\section{Texture of some products made from cow's milk versus vegan milk}

Chocolate pudding and Cheddar cheese were made from cow's milk versus some vegan milks and their blends. The data in Table (6) showed that the texture parameters of these products was obvious that pudding made from BRM exhibited the significantly $(\mathrm{P} \leq 0.05)$ highest values of the textural parameters (hardness, adhesiveness, springiness, gumminess and chewiness). In contrast, pudding made from AM had the significantly $(\mathrm{P} \leq 0.05)$ least value of hardness. Such a low value for hardness indicates possible difficulties in terms of handling and transportation of pudding made from AM.

In the present study, Cheddar cheese was made from BRM blends mixed with Am at different ratios. Assessment of texture for these samples revealed considerable variation in terms of hardness from $530 \mathrm{~g}(50 \% \mathrm{BRM}+50 \% \mathrm{AM})$ to $641 \mathrm{~g}$ (for $100 \%$ BRM) as shown in Table (6).

Adhesiveness ranged from $7.3 \mathrm{mj}$ (50\% BRM $+50 \% \mathrm{AM})$ to $11 \mathrm{mj}(100 \% \mathrm{BRM})$, while springiness ranged between $4.02 \mathrm{~mm}$ (50\% BRM $+50 \%$
$\mathrm{AM})$ to $5.48 \mathrm{~mm}(100 \% \mathrm{BRM})$. Regarding gumminess, it ranged from $168 \mathrm{~g}(50 \% \mathrm{BRM}+50 \% \mathrm{AM})$ to $206 \mathrm{~g}(100 \% \mathrm{BRM})$. On the other hand, Cheddar cheese made from $100 \%$ BRM exhibited the highest chewiness value being $7.6 \mathrm{mj}$, while cheese made from $(50 \% \mathrm{BRM}+50 \% \mathrm{AM})$ explored the least chewiness value (3.1mj) as shown in Table (6).

\section{The $\mathrm{pH}$ and viscosity of some food products made from vegan milks}

Four different food products were made from two vegan milks investigated in the present study (BRM and CM). Such products included strawberry flavoured milk, strawberry fermented milk, chocolate pudding and Cheddar cheese.

The $\mathrm{pH}$ values were significantly $(\mathrm{P} \leq 0.05)$ different and ranged from 6.60 (AM) to rice (6.74). On the other hand, strawberry flavoured milk exhibited $\mathrm{pH}$ values ranged from 5.03 (BRM) to 6.23 (cow's milk) as shown in Table (7). The $\mathrm{pH}$ values ranged between 4.0 for strawberry fermented milk made from $100 \%$ BRM to 4.73 for blend made from $50 \% \mathrm{BRM}+50 \% \mathrm{CM}$ (Table 7).

Table (7) shows that the $\mathrm{pH}$ values ranged from 6.63 for chocolate pudding made from CM to 8.04 for pudding made from $100 \% \mathrm{AM}$. Cheddar cheese made from $100 \%$ BRM along with that made from $90 \%$ BRM + CM had significantly $(\mathrm{P} \leq 0.05)$ least $\mathrm{pH}$ value (6.81) as shown in Table (7).

Viscosity (MPA) varied from 4.0 to 5.0 for cow's milk, rice milk coconut and almond milks.

Table 6: Texture of chocolate pudding and Cheddar cheese made from cow's milk and different vegan milk

\begin{tabular}{|c|c|c|c|c|c|c|}
\hline & \multirow[b]{2}{*}{ Samples } & \multicolumn{5}{|c|}{ Texture } \\
\hline & & $\begin{array}{l}\text { Hardness } \\
\text { (g) }\end{array}$ & $\begin{array}{c}\text { Adhesiveness } \\
\text { (mj) }\end{array}$ & $\begin{array}{l}\text { Springiness } \\
(\mathrm{mm})\end{array}$ & $\begin{array}{c}\text { Gumminess } \\
(\mathrm{g})\end{array}$ & $\begin{array}{c}\text { Chewiness } \\
\text { (mj) }\end{array}$ \\
\hline \multirow[t]{4}{*}{ chocolate pudding } & Cow's milk & $330^{c}$ & $6.0^{\mathrm{d}}$ & $2.48^{c}$ & $172^{\circ}$ & $4.2^{c}$ \\
\hline & Rice milk & $389^{a}$ & $7.3^{\mathrm{a}}$ & $3.18^{\mathrm{a}}$ & $181^{\text {a }}$ & $5.1^{\mathrm{a}}$ \\
\hline & Coconut milk & $343^{b}$ & $6.6^{\mathrm{b}}$ & $2.97 \mathrm{~b}$ & $170^{d}$ & $3.7^{\mathrm{d}}$ \\
\hline & Almond milk & $301^{\mathrm{d}}$ & $6.5^{\mathrm{c}}$ & $2.3^{\mathrm{d}}$ & $174^{b}$ & $4.3^{\mathrm{b}}$ \\
\hline \multirow[t]{4}{*}{ Cheddar cheese } & 100 rice milk & 641 & 11.0 & 5.48 & 206 & 7.6 \\
\hline & $\begin{array}{l}100 \% \text { rice milk }+10 \% \\
\text { almond milk }\end{array}$ & 571 & 10.7 & 5.14 & 198 & 6.4 \\
\hline & $\begin{array}{l}70 \% \text { rice milk + 30\% } \\
\text { almond milk }\end{array}$ & 557 & 8.8 & 4.76 & 183 & 5.3 \\
\hline & $\begin{array}{l}50 \% \text { rice milk }+50 \% \\
\text { almond milk }\end{array}$ & 530 & 7.3 & 4.02 & 168 & 3.1 \\
\hline
\end{tabular}

Super scrip letters following numbers in the same columns demote significant differences $(\mathrm{P} \leq 0.05)$ 
Strawberry flavoured milk exhibited viscosity values MPA ranged from 7 (AM) to 20 MPA (BRM). On the other hand, values ranged between 15 MPA (50\% BRM) and $20 \mathrm{MPA}(100 \% \mathrm{BRM})$ were recorded for strawberry fermented milk (Table 7).

As shown in Table (7) viscosity of chocolate pudding ranged between 5860 MPA (AM) and 5890 MPA (cow's milk). Notwithstanding, viscosity values ranged between 1430 and 1590 MPA, were recorded for Cheddar cheese made from $(50 \%$ $\mathrm{BRM}+50 \% \mathrm{CM}$ ) blend and cheese made from $100 \%$ BRM, respectively.

\section{Sensorial properties of products made from vegan milk}

The sensorial evaluation shown in Table (8) indicates that scores given by panelists were significantly $(\mathrm{P} \leq 0.05)$ different for vegan milks and their products. Almond milk in the strawberry blend of $(50 \%$ rice milk $+50 \%$ coconut milk) in the strawberry fermented milk. Also, the blends of $(70 \%$ rice milk $+30 \%$ almond milk) and $(50 \%$ rice milk $+50 \%$ almond milk) in the Cheddar cheese and cow's milk in the chocolate pudding have been ranked as superior in terms of colour.

Regarding the scores given for the taste by the panelists, it was obvious that the significantly $(\mathrm{P} \leq 0.05)$ highest scores were given for each of the following: the strawberry flavourd milk containing rice milk and almond milk. The highest scores were given for the three blends of the strawberry fermented milk $(50 \%$ rice milk $+50 \%$ coconut milk), (70\% rice milk $+30 \%$ coconut milk) and ( $90 \%$ rice milk $+10 \%$ coconut milk). Meanwhile for the Cheddar, cheese, the blend of $(50 \%$ rice milk $+50 \%$ almond milk) and $(70 \%$ rice milk + $30 \%$ almond milk) (Table 8).

The data given in Table (8), indicate that panelists gave the significantly $(\mathrm{P} \leq 0.05)$ highest scores to odour for coconut milk and almond milk for the strawberry fermented milk it was the blend of milk $50 \%$ rice milk $+50 \%$ coconut milk, for strawberry flavoured milk, while for the chocolate pudding it was cow's milk and no significantly $(\mathrm{P} \leq 0.05)$ dif-

Table 7: The pH and viscosity during refrigerated storage of vegan milks

\begin{tabular}{|c|c|c|c|}
\hline & Samples & pH & Viscosity (MPA) \\
\hline \multirow{4}{*}{ Milk } & Cow's milk & $6.65 \pm 0.07^{d}$ & $5 \pm 0.0^{\mathrm{e}}$ \\
\hline & Rice milk & $6.74 \pm 0.045^{\mathrm{c}}$ & $5 \pm 0.0^{\mathrm{e}}$ \\
\hline & Coconut milk & $6.34 \pm 0.024 \mathrm{e}$ & $4 \pm 0.0^{\mathrm{f}}$ \\
\hline & Almond milk & $6.6 \pm 0.039 \mathrm{~d}$ & $4 \pm 0.0^{\mathrm{f}}$ \\
\hline \multirow{4}{*}{ Strawberry flavoured milk } & Cow's milk & $6.23 \pm 0.106^{b}$ & $15 \pm 0.0^{\mathrm{b}}$ \\
\hline & Rice Milk & $5.03 \pm 0.04^{\mathrm{f}}$ & $20 \pm 0.0^{\mathrm{a}}$ \\
\hline & Coconut milk & $5.1 \pm 0.028^{\mathrm{ef}}$ & $8 \pm 0.0^{\mathrm{f}}$ \\
\hline & Almond milk & $5.75 \pm 0.021^{\mathrm{c}}$ & $7 \pm 0.0 \mathrm{~g}$ \\
\hline \multirow{4}{*}{ strawberry fermented milk } & 100\%Rice milk & $4.0 \pm 0.042^{\mathrm{e}}$ & $20 \pm 0.7^{\mathrm{a}}$ \\
\hline & $90 \%$ Rice milk $+10 \%$ Coconut milk & $4.1 \pm 0.021^{\mathrm{de}}$ & $18 \pm 0.7 \mathrm{c}$ \\
\hline & $70 \%$ Rice milk $+30 \%$ Coconut milk & $4.7 \pm 0.021^{\mathrm{a}}$ & $16 \pm 0.7 \mathrm{e}$ \\
\hline & $50 \%$ Rice milk $+50 \%$ Coconut milk & $4.73 \pm 0.024^{\mathrm{a}}$ & $15 \pm 0.0^{\mathrm{f}}$ \\
\hline \multirow{4}{*}{ chocolate pudding } & Cow’s milk & $7.04 \pm 0.034 \mathrm{e}$ & $5890 \pm 0.0^{\mathrm{a}}$ \\
\hline & Rice Milk & $7.66 \pm 0.061^{\mathrm{c}}$ & $5870 \pm 0.0^{c}$ \\
\hline & Coconut milk & $6.63 \pm 0.067 \mathrm{~g}$ & $5860 \pm 0.0^{\mathrm{d}}$ \\
\hline & Almond milk & $8.04 \pm 0.065^{\mathrm{a}}$ & $5880 \pm 0.0^{\mathrm{b}}$ \\
\hline \multirow{4}{*}{ Cheddar cheese } & $100 \%$ Rice milk & $7.53 \pm 0.028^{\mathrm{b}}$ & $1590 \pm 7.07^{\mathrm{a}}$ \\
\hline & $90 \%$ Rice milk $+10 \%$ Coconut milk & $7.51 \pm 0.014^{\mathrm{b}}$ & $1490 \pm 21.21^{\mathrm{b}}$ \\
\hline & $70 \%$ Rice milk $+30 \%$ Coconut milk & $7.15 \pm 0.014^{\mathrm{d}}$ & $1450 \pm 21.21^{\mathrm{c}}$ \\
\hline & $50 \%$ Rice milk $+50 \%$ Coconut milk & $6.81 \pm 0.014^{\mathrm{f}}$ & $1430 \pm 21.21^{\mathrm{d}}$ \\
\hline
\end{tabular}

Data are means \pm standard deviations of three replicates 
Table 8: Sensorial attributes of cows and vegan milks stored at ${ }^{\circ} \mathrm{C}$ for different storage periods

\begin{tabular}{|c|c|c|c|c|c|c|}
\hline & Samples sterilization & $\begin{array}{c}\text { Colour } \\
(5 \text { points })\end{array}$ & $\begin{array}{c}\text { Taste } \\
(5 \text { points })\end{array}$ & $\begin{array}{c}\text { Odour } \\
\text { (5 points) }\end{array}$ & $\begin{array}{c}\text { Texture } \\
(5 \text { points })\end{array}$ & $\begin{array}{c}\text { Overall } \\
\text { (5 points) }\end{array}$ \\
\hline \multirow{4}{*}{ Milk } & Cow's milk & $3.75 \pm 1.38^{\mathrm{fg}}$ & $3.56 \pm 1.23^{\mathrm{efg}}$ & $3.43 \pm 1.23^{\mathrm{gh}}$ & $3.43 \pm 1.11^{\mathrm{gh}}$ & $3.67 \pm 1.14^{\mathrm{fg}}$ \\
\hline & Rice milk & $2.31 \pm 1.22^{\mathrm{n}}$ & $2.68 \pm 0.79 \mathrm{mno}$ & $3.75 \pm 0.84^{\mathrm{ef}}$ & $3.0 \pm 1.03^{\mathrm{i}}$ & $3.12 \pm 0.68^{\mathrm{jk}}$ \\
\hline & Coconut milk & $4.18 \pm 0.65^{\mathrm{cd}}$ & $3.43 \pm 0.62^{\mathrm{ghi}}$ & $3.938 \pm 0.56^{\text {cde }}$ & $3.375 \pm 0.58^{\mathrm{h}}$ & $3.89 \pm 0.49$ de \\
\hline & Almond milk & $3.62 \pm 1.3^{\mathrm{ghi}}$ & $2.62 \pm 1.18^{\mathrm{no}}$ & $2.938 \pm 1.42^{\mathrm{jk}}$ & $2.938 \pm 0.776^{\mathrm{ij}}$ & $3.18 \pm 1.09 \mathrm{jk}$ \\
\hline \multirow{4}{*}{$\begin{array}{l}\text { Strawberry } \\
\text { flavoured }\end{array}$} & Cow's milk & $3.12 \pm 1.08^{\mathrm{h}}$ & $2.75 \pm 1.12^{\mathrm{e}}$ & $3.75 \pm 1.16^{\mathrm{e}}$ & $3.5 \pm 1.09^{\mathrm{c}}$ & $3.63 \pm 1.27 \mathrm{~g}$ \\
\hline & Rice milk & $4.25 \pm 0.96^{\mathrm{d}}$ & $3.63 \pm 0.97^{\mathrm{a}}$ & $4.0 \pm 1.12^{\mathrm{cd}}$ & $4.0 \pm 1.12^{\mathrm{a}}$ & $4.25 \pm 1.034^{\mathrm{b}}$ \\
\hline & Coconut milk & $4.5 \pm 1.12^{\mathrm{b}}$ & $3.25 \pm 1.03^{\mathrm{b}}$ & $4.5 \pm 0.93^{\mathrm{a}}$ & $3.88 \pm 1.23^{\mathrm{a}}$ & $4.0 \pm 1.05^{\mathrm{d}}$ \\
\hline & Almond milk & $4.62 \pm 1.12^{\mathrm{a}}$ & $3.63 \pm 1.33^{\mathrm{a}}$ & $4.5 \pm 1.26^{\mathrm{a}}$ & $3.75 \pm 1.074^{\mathrm{b}}$ & $4.38 \pm 1.083^{\mathrm{a}}$ \\
\hline \multirow{4}{*}{$\begin{array}{l}\text { strawberry } \\
\text { fermented milk }\end{array}$} & 100\%Rice milk & $3.96 \pm 1.09 \mathrm{e}$ & $3.93 \pm 1.12^{\mathrm{c}}$ & $4.109 \pm 1.12^{\mathrm{ef}}$ & $4.51 \pm 0.94^{a}$ & $3.93 \pm 0.67 \mathrm{ef}$ \\
\hline & $\begin{array}{l}90 \% \text { Rice milk }+10 \% \\
\text { Coconut milk }\end{array}$ & $3.95 \pm 0.92^{\mathrm{e}}$ & $4.45 \pm 1.02^{\mathrm{a}}$ & $4.28 \pm 1.12^{\mathrm{cd}}$ & $4.413 \pm 0.87^{\mathrm{ab}}$ & $4.2 \pm 1.21^{\mathrm{c}}$ \\
\hline & $\begin{array}{l}70 \% \text { Rice milk }+30 \% \\
\text { Coconut milk }\end{array}$ & $4.53 \pm 1.36^{\mathrm{b}}$ & $4.53 \pm 1.02^{\mathrm{a}}$ & $4.459 \pm 1.06^{\mathrm{b}}$ & $4.3 \pm 0.99 \mathrm{bc}$ & $4.53 \pm 0.92^{\mathrm{b}}$ \\
\hline & $\begin{array}{l}50 \% \text { Rice milk }+50 \% \\
\text { Coconut milk }\end{array}$ & $4.8 \pm 0.96^{\mathrm{a}}$ & $4.63 \pm 0.91^{\mathrm{a}}$ & $4.63 \pm 0.81^{\mathrm{a}}$ & $3.98 \pm 0.84^{\mathrm{f}}$ & $4.78 \pm 1.12^{\mathrm{a}}$ \\
\hline \multirow{4}{*}{$\begin{array}{l}\text { chocolate } \\
\text { pudding }\end{array}$} & Cow's milk & $5.0 \pm 1.09^{\mathrm{a}}$ & $4.83 \pm 0.93^{\mathrm{a}}$ & $4.83 \pm 0.88^{\mathrm{a}}$ & $4.5 \pm 0.89^{b}$ & $19.40 \pm 1.16^{\mathrm{a}}$ \\
\hline & Rice milk & $3.67 \pm 1.34^{\mathrm{h}}$ & $3.83 \pm 1.42^{\mathrm{h}}$ & $4.17 \pm 0.93^{\mathrm{f}}$ & $4.17 \pm 1.12^{\mathrm{d}}$ & $17.68 \pm 1.21^{\mathrm{b}}$ \\
\hline & Coconut milk & $3.5 \pm 1.09 \mathrm{j}$ & $3.5 \pm 1.31^{\mathrm{j}}$ & $4.0 \pm 1.38^{\mathrm{h}}$ & $3.17 \pm 1.41^{\mathrm{h}}$ & $16.48 \pm 1.064^{\mathrm{cd}}$ \\
\hline & Almond milk & $4.83 \pm 0.92^{\mathrm{g}}$ & $4.0 \pm 1.17 \mathrm{~g}$ & $4.17 \pm 1.33^{\mathrm{f}}$ & $3.67 \pm 1.26^{\mathrm{f}}$ & $17.68 \pm 1.12^{\mathrm{b}}$ \\
\hline \multirow{4}{*}{ Cheddar cheese } & 100\%Rice milk & $3.625 \pm 1.22^{\mathrm{f}}$ & $4.19 \pm 1.09^{b}$ & $4.86 \pm 1.26^{\mathrm{a}}$ & $4.8 \pm 1.03^{\mathrm{a}}$ & $17.20 \pm 1.29^{\mathrm{b}}$ \\
\hline & $\begin{array}{l}90 \% \text { Rice milk }+10 \% \\
\text { almond milk }\end{array}$ & $3.875 \pm 0.82^{\mathrm{e}}$ & $4.06 \pm 1.25^{\mathrm{c}}$ & $4.88 \pm 1.22^{\mathrm{a}}$ & $4.13 \pm 1.22^{\mathrm{d}}$ & $17.24 \pm 1.36^{\mathrm{b}}$ \\
\hline & $\begin{array}{l}70 \% \text { Rice milk }+30 \% \\
\text { almond milk }\end{array}$ & $4.375 \pm 1.24^{a}$ & $4.69 \pm 1.19 \mathrm{a}$ & $4.81 \pm 1.27^{\mathrm{a}}$ & $4.69 \pm 1.09 \mathrm{~b}$ & $18.56 \pm 1.06^{\mathrm{a}}$ \\
\hline & $\begin{array}{l}50 \% \text { Rice milk }+50 \% \\
\text { almond milk }\end{array}$ & $4.25 \pm 1.02^{\mathrm{b}}$ & $4.75 \pm 1.23^{\mathrm{a}}$ & $4.83 \pm 1.19^{\mathrm{a}}$ & $4.0 \pm 0.79 \mathrm{e}$ & $18.84 \pm 1.01^{\mathrm{a}}$ \\
\hline
\end{tabular}

Data are means \pm standard deviations of three replicates

Means in a column not sharing the same letter are significantly $(\mathrm{P} \leq 0.05)$ different.

ference could be found in the odour of the Cheddar cheese samples prepared in the present study (Table 8 ).

The significantly $(\mathrm{P} \leq 0.05)$ highest scores given by panelists to texture were for each of for following: for the strawberry milk: rice milk and coconut milk. For the strawberry fermented milk it was ( $100 \%$ rice milk) and for the cheddar cheese $100 \%$ rice milk (Table 8).

It was obvious that each of the following products gained the significantly highest $(\mathrm{P} \leq 0.05)$ scores given for overall acceptability: Almond milk in the strawberry milk, blend of $(50 \%$ rice milk $+50 \%$ coconut milk) in the strawberry fermented milk. Meanwhile, blends of milk (50\% rice milk $+50 \%$ almond milk) and (70\% rice milk $+30 \%$ al- mond milk), were for Cheddar cheese and chocolate pudding along with the cow's milk (Table 8). Consequently, it is advisable to manufacture the aforementioned products from vegan milks to insure their high acceptability by the consumers.

\section{Microbiological quality of products made from vegan milk}

In the present study, four food products were made from two vegan milks (BRM and CM). These products were microbiologically investigated in terms of the following parameters: Total count, aerobic spore forming bacteria, coliform, moulds \&yeasts, psychrophilic bacteria and probiotic growth .No microorganisms could be detected in one millileter. The only exception was strawberry 
fermented milk that exhibited the following probiotic growth:

$$
\begin{aligned}
& 5 \times 10^{5} \mathrm{CFU} / \mathrm{g}(100 \% \mathrm{BRM}), \\
& 13.7 \times 10^{5} \mathrm{CFU} / \mathrm{g}(90 \% \mathrm{BRM}+10 \% \mathrm{CM}), \\
& 19 \times 10^{5} \mathrm{CFU} / \mathrm{g}(70 \% \mathrm{BRM}+30 \% \mathrm{CM}), \text { and } \\
& 36 \times 10^{5} \mathrm{CFU} / \mathrm{g} \mathrm{m}(50 \% \mathrm{BRM}+50 \% \mathrm{CM}) .
\end{aligned}
$$

Data are mean values of triplicate analysis. Super scrip letters following numbers in the same row demote significant differences $(\mathrm{P} \leq 0.05)$ attributes

\section{REFERENCES}

AOAC, 2006. Official Methods of Analysis. 15th Ed., Association of Official Analysis Chemists Inc., USA.

Duncan, D.B. 1955. Mulitple range and multiple F tests. Biometrics, 11: 1-42

Harrigan, W.F. \& McCance, M.E. 1976. Laboratory Methods in Microbiology, Academic press, London and New York, US

International Dairy Federation, 1991. Rheological and fracture properties of cheese, IDF Bulletin 268. International Dairy Federation. Brussels, Belgium.

Kartz, G., Yang, M., Sanchez, A. \& Silverstein, R. 2014. Oxidized LDL Signaling "Primes" GPVI-Mediated Platelet Activation in a CD36Dependent Manner. Arteriosclerosis, Thrombosis, and Vascular Biology, 34 (suppl_1), A382-A382.

Kartz, G.A., Holme, R.L., Nicholson, K. \& Sahoo, D. 2014. SR-BI/CD36 chimeric receptors define extracellular subdomains of SR-BI critical for cholesterol transport. Biochemistry, 53: 6173-6182.

Katz M.J., Acevedo, J.M. \& Wappner, P. 2014. Growing with the wind. Ribosomal protein hydroxylation and cell growth. Fly (Austin) 8:153-6.

Kleessen, B., Stoof, G., Proll, J. Schmicdl, D., Noack, J. \& Blaut, M. 1997. Feeding resistant starch affects fecal and cecal microflora and short-chain fatty acids in rates. Journal of Animal Science, 75: 2453-2462.

Kolapo, A.L. \& Olubamiwa, A.O. 2012. Effect of different concentrations of coconut milk on the chemical and sensory properties of soycoconut milk based yoghurt. Food and Public Health, 2: 85-91.

Lee, G. J., Birken, C. S., Parkin, P. C., Lebovic, G., Chen, Y., L'Abbé, M. R. \& TARGet Kids Collaboration, 2014. Consumption of noncow's milk beverages and serum vitamin D levels in early childhood. Canadian Medical Association Journal, cmaj-140555.

M. Abd El-Aziz, Mohamed, S.H.S., Seleet, F.L., Abd El-Gawad, M.A.M. 2015. "Effect of Brine Solution Containing Ginger Extracts on the Properties of Egyptian White Brined Cheese", American Journal of Food Technology.

Mäkinen, O. E., Wanhalinna, V., Zannini, E. \& Arendt, E. K. 2016. Foods for special dietary needs: Non-dairy plant-based milk substitutes and fermented dairy-type products. Critical reviews in food science and nutrition, 56: 339-349.

Nilsson, L., Lyck, S., and Tamime, A. 2006. Production of drinking products. In: Fermented Milks. Tamime, A. (Ed). Blackwell Sci, UK, Vol. 5.

Practice-based Evidence in Nutrition. Are Plantbased Beverages Sui Table For Lee, J. G. 2015. Consumption of Non-cow's Milk and 25-Hydroxyvitamin D Levels in Early Childhood (Doctoral Dissertation).

Schott, L., \& Bernard, J. 2015. Comparing Consumer's Willingness to Pay for Conventional, Non-Certified Organic and organic Milk from Small and Large Farms. Journal of Food Distribution Research, 46: 186-205.

Tamime, A.Y., Skriver, A., \& Nilsson, L. E. 2006. Starter cultures. In: Fermented milks, Tamime, A. (Ed). Blackwell Sci, UK, Oxford, pp. 11-52.

USDA (United States Department of Agriculture) 2013. CropScape cropland data layer. Washington, DC: National Agricultural Statistics Service.

Wehr, H.M., \& Frank, J.F., American Public Health Association (Eds.) 2004. Standard methods for the examination of dairy products (pp. 327-404). Washington, DC: American Public Health Association. 


\section{تكوين وتقييم بعض المنتجات الفذائية الجديلة الهحتوية على الألبان النباتية}

آية محمد الحسيني'، سمير محمد أحمد' ، إيهاب عيسي خضرَ'، سهير فؤاد نور'،

ا - قسم الاقتصاد المنزلى - كلية الزراعة- جامعة الاسكندرية.

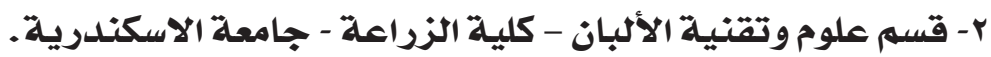

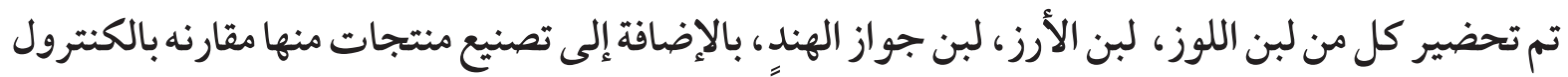

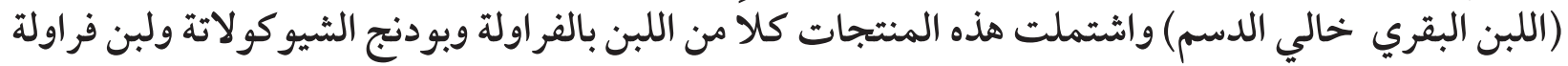
متخمر، جبن شيدر قابل للفرد.

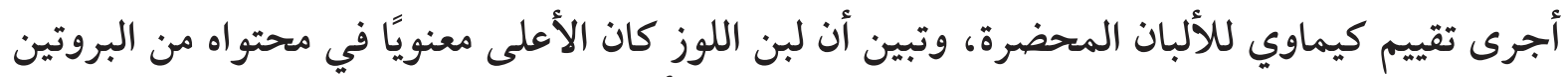

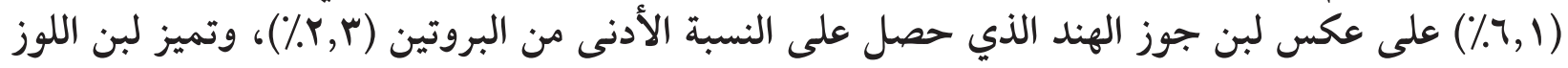

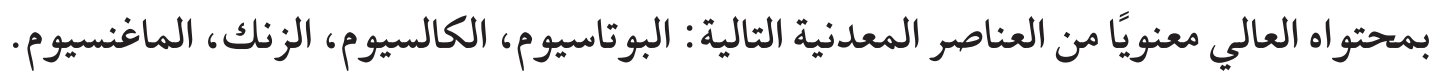

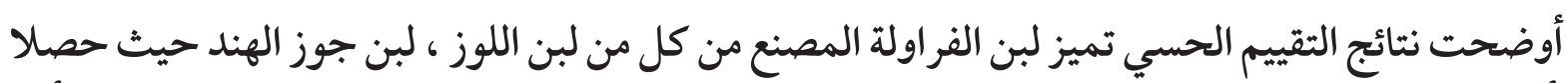

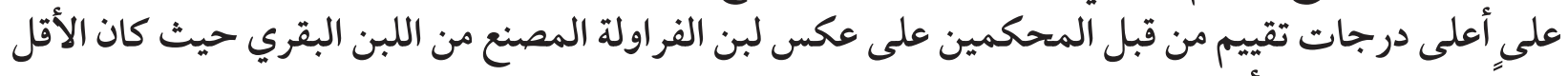

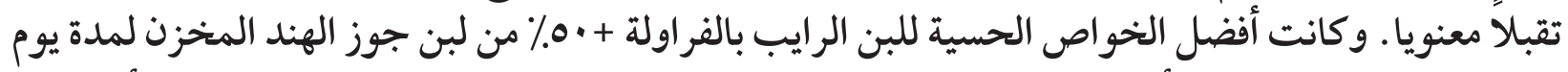

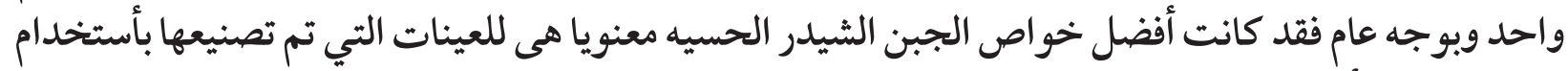

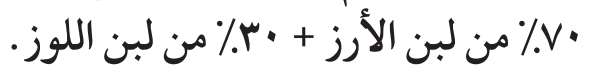

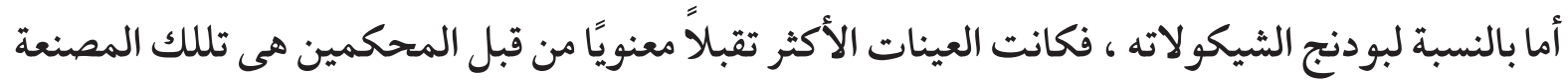

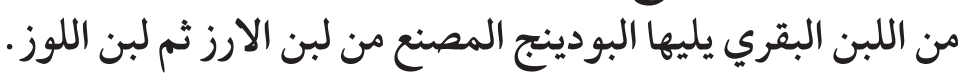

